\title{
Aging - a Demographic and an Economic Problem
}

\author{
By JARL LINDGREN
}

The Population Research Institute

The change in the age structure is a feature characteristic of the final phase of demographic transition. As a consequence the number of those living on old-age and disability pension increases. The continuing increase in the number of the retired has aroused lively debate in many countries. The debate is primarily focused on the question of how the growing expenditures of social insurance can be financed. It is feared that the relation between the economically active population and the economically inactive population will become too unfavorable, so that the dependency ratio will increase excessively. The recession and decreasing economic growth have given the discussion new vigor and have revealed new aspects in the situation. In some countries the basic pension system has already encountered difficulties. In Finland we have yet to meet them.

Measured by international standards the age structure of the Finnish population is today quite favorable. The working-age population forms a satisfactory part. However, during the coming decades the age structure will get older faster and faster. According to the population projection drawn up by the Central Statistical Office of Finland in 1978 (CSO 1978), the number of the retired will continue to increase up to the year $2020 .{ }^{1}$ In 1978 the number of persons over 65 years of age was 542000 or a good 11 per cent of the whole population. According to the projection the number of the retired in 2020 will be 921000 or 19 per cent (Table 1 ).

At the end of 1975 there was one man to 1.7 women who had reached 65 years of age. According to the projection the corresponding figure will be 1.5 at the end of the year 2020 .

The projection is based on the hypothesis that the birth rate will stabilize in the coming years on a slightly higher level than in 1978 the total fertility being 1.75 from 1985 on. Net out-migration has been calculated at a total of 15000 in 1978-1980, and after this it is assumed that outmigration will reach equilibrium. Mortality is supposed to slow down according to the latest developments and the death of men to decrease faster than that of women.

According to calculations made by the Social Insurance Institute the number of disabled persons will increase from the present level by nearly 40 per cent

1 The information on the year 2020 has been obtained from the unpublished calculations of the Central Statistical Office. 
before the year 2010 and after this the figures will begin to diminish (Ryynänen 1979). The vigorous growth at the end of the 20th century can be explained by the fact that the large cohorts born after the Second World War will be

$\mathrm{Table} 1$. The age structure of the population in $1970-2020$.

1970

1980

1990

2000

2010

2020

\begin{tabular}{rr}
\multicolumn{2}{c}{$0-14$} \\
Number & $\%$ \\
1118550 & 24,3 \\
963100 & 20,1 \\
965000 & 19,6 \\
888000 & 18,0 \\
812000 & 16,7 \\
790000 & 16,6
\end{tabular}

\begin{tabular}{cc}
\multicolumn{2}{c}{$15-64$} \\
Number & $\%$ \\
& \\
3052298 & 66,4 \\
3250000 & 67,9 \\
3323200 & 67,3 \\
3366600 & 68,1 \\
3317300 & 68,1 \\
3043000 & 64,0
\end{tabular}

\begin{tabular}{rr}
\multicolumn{2}{c}{$65-$} \\
Number & $\%$ \\
& \\
427488 & 9,3 \\
573800 & 12,0 \\
644000 & 13,1 \\
688700 & 13,9 \\
740000 & 15,2 \\
921000 & 19,4
\end{tabular}

reaching the age groups where the disability rate is highest. Correspondingly, the decrease after the year 2010 is due to the fact that the large cohorts will then enter the old-age pension age (Table 2). As the working-age population in the beginning of the 21st century decreases, the share of the disabled will, however, remain practically unchanged.

Table 2. Number of persons receiving disability pension and their proportion of the working-age population (15-64-year-olds) in 19702020 .

$\begin{array}{rrr} & & \% \\ 1970 & 172000 & 5.6 \\ 1980 & 251000 & 7.7 \\ 1990 & 269000 & 8.0 \\ 2000 & 296000 & 8.8 \\ 2010 & 345000 & 10.4 \\ 2020 & 311000 & 10.2\end{array}$

The projection of the number of persons receiving disability pension is based on variables at the 1977 level.

When one adds together persons aged 65 and over and those receiving disability pension, the proportion of pensioners will increase from 1970 when it was 14 per cent of the whole population to 26 per cent in 2020 (Table 3).

Figure 1 gives an overview of the main population groups in 1975-2020. As shown in the figure the Finnish population will increase according to the projection to almost five million people by the year 1995 and will decrease after that by two hundred thousand persons by the year 2020 . 
Figure 1. Economically active and inactive population in 1975-2020.

Million

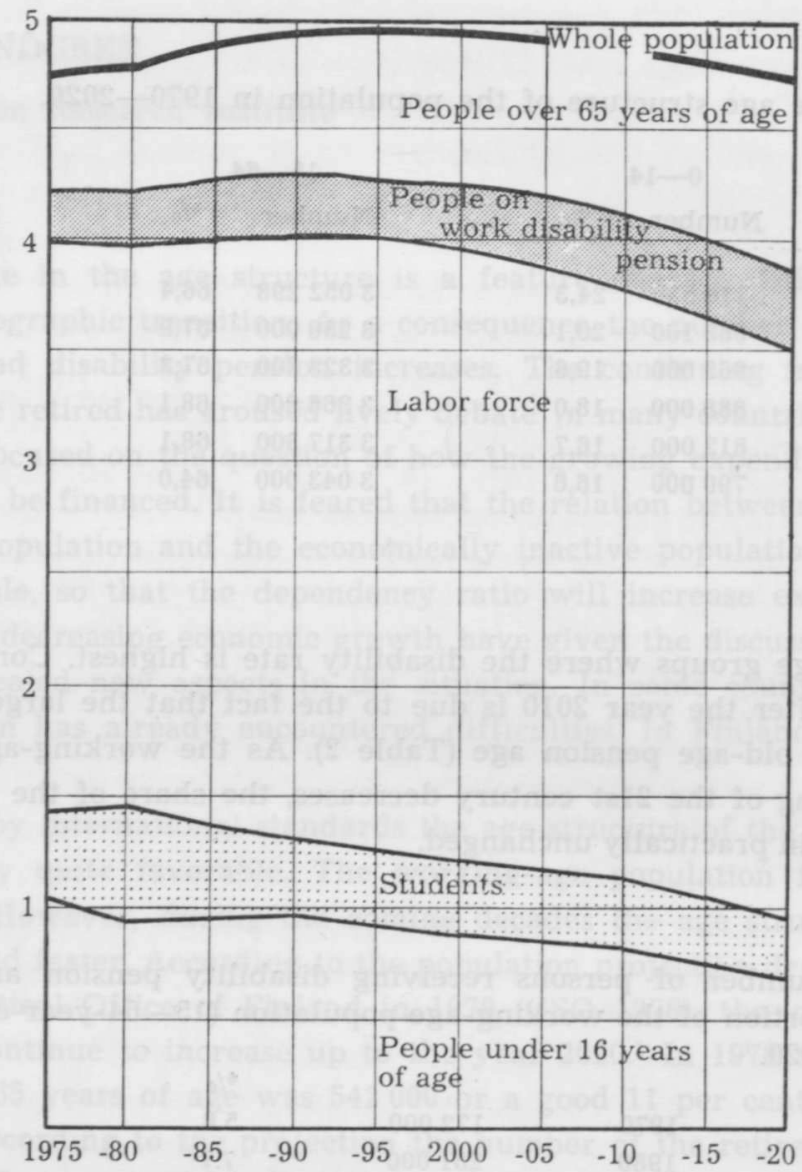

At the end of the 1970 s there will be one retired person to about four persons belonging to the labor force. The corresponding proportion in 2020 will be one retired person to two and a half person. At the same time as the number of retired persons increases fertility will decrease and the number of children will diminish. The crude birth rate will decline according to the population projection from 13.8 in 1977 to 10.6 in 2020 (Table 4). This is not a consequence of the decrease in fertility but of the change in the age structure: the number of women of childbearing age (15-44 years of age) will begin to decrease in the 1980 s and by 2020 they will number about 20 per cent less than in 1978. 
If students aged $15-24^{2}$ are added to the number of retired and disabled persons the dependency ratio will be even worse. In the late 1970 s there were seven dependents - retired and disabled persons and students - to eight

$\mathrm{Table} 3$. The number of 65-year-olds and disabled persons and their proportion of the whole population in the years $1970-2020$.

$\begin{array}{rrr} & & \% \\ 1970 & 629000 & 4.4 \\ 1980 & 838000 & 3.8 \\ 1990 & 918000 & 2.5 \\ 2000 & 989000 & 3.4 \\ 2010 & 1090000 & 3.0 \\ 2020 & 1236000 & 2.4\end{array}$

providers - i.e. persons in the labor force. In 2020 there will be approximately as many dependents as providers. Thus the ratio will be nearly the same in the

$\mathrm{T}$ a ble 4. Live births and crude birth rate in $1977-2020$.

$\begin{array}{ccc} & \text { Number } & \begin{array}{c}\text { Per } \\ \text { thousand }\end{array} \\ 1977 & 65681 & 13,8 \\ 1980 & 64500 & 13,5 \\ 1990 & 62600 & 12,7 \\ 2000 & 54700 & 11,1 \\ 2010 & 53900 & 11,1 \\ 2020 & 50300 & 10,6\end{array}$

beginning of the 21 st century as at the end of the 1970 s assuming that the consumption of a child is equal to that of a retired or disabled person.

In general the average consumption of retired persons is considerer to be greater than that of children. According to a study made in Sweden in 1975 the total consumption of a retired person in Sweden in 1975 including both

2 For reasons of simplification it is assumed that the economically inactive 15-24years-old are students and that this portion will stay unchanged during the whole period investigated, i.e. at the same level as in 1978 or 70 per cent of the 15-19-yearolds and 32 per cent of the 20-24-year-olds (Ministry of Labor 1979, 30). There are, of course, students in the older age groups also but less: only 10 per cent of the men aged 25-29 were economically inactive and 24 per cent of the women of the same age group. It is, however, evident that part of the economically inactive women are on maternity leave or housewives. Part of the students are also working part time and thus are included in labor force. Hence a calculation based on these figures gives only a rough picture of the number of future students. 
private and public consumption, was 80 per cent of that of a gainfully occupied person while the consumption of a child was 40 per cent ( $\AA$ berg-Nordin 1977, 81). In the same study it is assumed that by 2020 the consumption of a retired person will be on the same level as that of a gainfully occupied person while the consumption of a child will equal one-half. If the same proportions are used here and the consumption of a disabled person considered equal to that of a retired person the dependency ratio will grow from 0.6 at the end of the 1970 s to 0.7 in 2020 . The trivial growth is a consequence of the labor force remaining numerically about the same during the whole period.

The projection made by the Central Statistical Office provides information necessary for making a comparison of those leaving the labor force and those entering it, provided the age group $60-64$ years represents those retiring and the age group 15-19 years those entering it.

The growth of the labor force will slow down rapidly in the 1980 s and this trend will continue until 2005 though to a lesser degree than in the 1970 s and 1980s (Figure 2). About 2000 those leaving the labor force will exceed those entering the labor force. The situation will remain unaltered until the end of the period investigated. Along with the aging of the population the structure of the labor force will change. The mean age will rise and the portion of the older year groups increase.

Fig ure 2. Persons leaving and entering the labor force in 1975-2020.

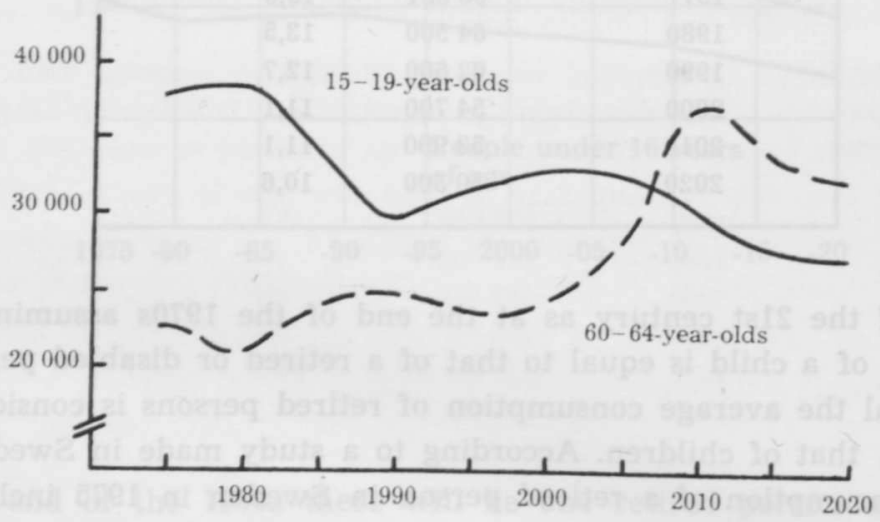

It has to be mentioned that the relation between those entering and those leaving the labor force would have remained nearly the same if the $20-24$ year-olds or the five years mean of the 15-19 and 20-24 year groups would have been used in the calculations to represent those entering the labor force.

The change occurring in the age structure has begun to arouse anxiety. Efforts have been made to find out how the increasing number of the retired will affect the growth of social expenses. 
This is, however, a difficult task especially if one wants to extend the investigation period up to the years when the number of pensioners will reach its culmination point i.e. to the $2020 \mathrm{~s}$. When working with long-term prognosis there are numerous uncertainties, and views concerning economic growth diverge strongly. The burden caused by the retired depends on several factors, but especially on the economic growth as well as on the demand and supply of the labor force in the society.

The rise in pension expenditures is not only due to the growth in the number of pensioners but also to the continuing increase in the nominal size of the pension. The ultimate goal - a pension of 60 per cent for all employees cannot be reached until 2002. At the moment six out of ten employees going on old-age or work disability pension are receiving minimum pension at the most and this is 35 per cent of their wage (Hänninen 1978).

According to a projection made up to 2000 pension costs will rise from the present 11 per cent of social security cost to 34 per cent, totaling about 10 per cent of the GNP. Simultaneously the ratio of social security costs to the GNP would increase from 21 per cent to 26 per cent (Pentikäinen, 1979). Obviously, this is not too large a share from an international standpoint. The projection is based on a three per cent yearly rise in the real GNP. Consequently, if the growth of the GNP remains smaller the ratio will be even greater.

By 2020 pension costs are estimated at 15-16 per cent of the GNP, if the annual real growth of the GNP is three per cent. At the same time the pensions costs of wages and salaries would grow from the present seven per cent to 30 per cent.

An average of three per cent annual real growth in the 1900 s could still be plausible, but it could be considered rather high in the $2000 \mathrm{~s}$ if we take into account the increasing anxiety about the overuse of natural resources and the widening importance of the protection of the environments. Thus in a Swedish projection up to 2025 an average yearly economic growth is restricted to $0.9-$ 1.3 per cent ( $\AA$ berg-Nordin 1978). Consequently, one does not seem to be unrealistic if one assumes that the pension costs in Finland in 2020 will exceed 16 per cent of the GNP.

The rise of social security costs in favor of the retired will cause a slower growth in the consumption level of the active population. If the real growth of the GNP is three per cent annually the increase in the level of pensions is calculated at 3.5 per cent for each pensioner (Koljonen-Tuovinen 1979, 38). Hence, the income of the pensioners will increase more than that of the economically active population:

$\begin{array}{lcc} & \text { available } & \text { income per person } \\ & 1976 & 2000 \\ \text { wage earners } & 115 & 100 \\ \text { pensioners } & 94 & 115\end{array}$


If the growth rate is smaller than three per cent consumption level of the economically active will drop more quickly. In 2020 the gap between the available income of the two population groups will be even wider if the future pension schemes are realized according to current legislation.

Pensions are connected in many ways with the whole national economy. They do not only use economic resources but also produce them. For the present we, however, lack a coherent picture of the effects of the aging on society and its different sectors. To be able to neutralize possible harmful side effects of aging in the future the whole domain should be studied in all its ramifications now - not when the difficulties are with us.

\section{References}

CSO: Population projection by municipalities 1978-2020. Statistical report, VA 1978: 17 Hänninen, Markku: Työeläketurvan rahoitus. Sosiaalivakuutus N:o 9-10, 1978

Koljonen, Kalevi \& Tuovinen, Marja: Sosiaaliturva ja sen rahoitus Kansantaloudessa. Taloudellinen suunnittelukeskus. Erillisselvitys 2/1979

Ministry of Labour: Labour Reports, 22, Vol 1, 1979

Pentikäinen, Teivo: Sosiaalikustannukset kansantaloudessa. Sosiaalinen aikakauslehti, N:o 4,1979

Pentikäinen, Teivo: Eläkekustannusten kasvuennusteita. Sosiaalinen aikakauslehti, N:o 4, 1979

Ryynänen, Markku: Kansaneläkkeen saajat vuonna 2020. Sosiaalivakuutus N:o 3-4, 1979

Åberg, Carl-Johan \& Nordin, Allan: Befolkning och ekonomi. Trygg-Hansa tryckeri, Stockholm 1977. 